International Journal of Current Microbiology and Applied Sciences

ISSN: 2319-7706 Volume 9 Number 6 (2020)

Journal homepage: http://www.ijcmas.com

Review Article

https://doi.org/10.20546/ijcmas.2020.906.299

\title{
Agro-Industrial Solid Biodegradable Waste as a Source of Pectin and Feed for Livestock Farm-An Appraisal
}

\author{
Devina Vaidya ${ }^{1}$, Anil Kumar Verma ${ }^{2 *}$, Anil Gupta ${ }^{1}$, Manisha Kaushal ${ }^{1}$, \\ Shivani $^{2}$ and Vinay Chandel $^{1}$
}

${ }^{1}$ Department of Food Science and Technology, Dr. Y.S. Parmar University of Horticulture and Forestry, Nauni, Solan, India

${ }^{2}$ Department of Food Science and Technology, College of Horticulture and Forestry,

Dr.Y.S. Parmar University of Horticulture and Forestry, Neri,

Hamirpur, (H.P)-177 001, India

*Corresponding author

\section{A B S T R A C T}

\begin{tabular}{|l|}
\hline Ke y w o r d s \\
Apple pomace, \\
pectin, extraction, \\
value added \\
products, animal \\
feed
\end{tabular}

Pectin is becoming increasingly popular as an effective additive in food industry because of its gelling, stabilizing, thickening and emulsifying properties. From the entire production of apple across the world about 71 per cent of apple is consumed as fresh apple while about 25-29 per cent is transformed into value -added products of which 65 per cent are processed into apple juice concentrate (AJC) and the balance quantity into other products which include packed natural ready-to-serve (RTS) apple juice, apple cider, wine and vermouth, apple purees, jams and dried apple products etc. The conventional processing of this fruit for juice, cider and concentrate preparation removes 75 per cent of fresh weight as juice and remaining 25 per cent as solid waste, known as apple pomace that is considered to be rich source of sugars (17.35\%), pectin (16.95\%) and crude fibre $(16.16 \%)$ with a very high biological oxygen demand i.e. $240-19000 \mathrm{mg} / \mathrm{l}$. Apple pomace could also be utilized directly as animal feed or for the extraction of value-added products like pectin. Acids, alkalines and enzymes treatments have been employed to extract pectin from various sources, but pectin isolation is mainly predominated by the conventional acid hydrolysis of plant raw material and extraction with pectolytic enzymes. Pectins are industrially obtained from apple pomace and citrus peels in a chemical way with strong acids such as oxalic, hydrochloric, nitric and sulphuric acids which are regarded as conventional acid extraction methods. Enzymatic extraction has been conducted with polygalacturonase, hemicellulose and cellulase, protease and microbial mixed enzymes. Also, a number of methods have been used to extract pectin like ultrasonic, autoclave, microwave and extrusion assisted treatments from agricultural by -products such as apple pomace, sugar beet pulp and orange peels. The commercial production of apple fiber powder from the pomace after extraction of juice has been practiced by certain companies in abroad (Tree Top Inc, Selah, W.A.), However, in India technology for extraction of pectin on commercial scale from apple pomace is yet to be developed. The present reviews critically analyse the Extraction, Characterization and Applications of pectin obtained from apple pomace.

\section{Introduction}

Apple pomace being biodegradable in nature with high bio-chemical oxygen demand (BOD) and its direct disposal into the environment causes pollution (Kaushal et al., 2002). Approximate proportions of various morphological constituents of apple pomace are pulp (54\%), peel (34\%), seeds (7\%) seed core $(4 \%)$ and stalks (2\%). Chemically, the 
Pomace is known to contain 66.4-78.2\% moisture, $26.4 \%$ dry matter (DM), 9.5-22.0 $\%$ carbohydrates, $4.0 \%$ proteins, $3.6 \%$ sugars, $6.8 \%$ cellulose, $0.38 \%$ ash, $0.42 \%$ acid and $8.7 \mathrm{mg} / 100 \mathrm{~g}$ calcium on wet weight basis (Vasil'ev et al., 1976; Sun et al., 2007). Joshi and Attri (2006) reported that apple pomace contained $48.00 \%$ total sugar, 5.80 $\%$ crude protein, $14.70 \%$ crude fibre, 18.50 $\mathrm{mg} / 100 \mathrm{~g}$ vitamin $\mathrm{C}$ and total $1.82 \%$ ash on dry weight basis. Owing to high carbohydrate content, apple pomace is used as a substrate in a number of microbial processes for the production of organic acids, enzymes, single cell proteins, ethanol, low alcoholic drinks and pigments etc. (Bhushan et al., 2008). Pectic substances in fruits were discovered by the French chemist Louis Nicolas Vauquelin in 1790 in tamarind fruit (Vauquelin, 1790). The term "pectin" was introduced by Henry Braconnot in 1825 from the Greek word 'pektikos' meaning to congeal or solidify (Braconnot, 1825). Pectic polysaccharides, localized in the primary cell wall and middle lamella in all higher plants, are responsible for different physiological processes (Knox, 2002). In the cell walls they serve as one of the main agents cementing the cellulose fibrils and may be linked covalently to other polymers. Intracellular pectins provide the channels for passage of nutrients and water (Tamaki et al., 2008). Apple pomace is rich source of pectic substances (Fox, 1984).

Pectin is defined as a mixture of heteropolysaccharides. The polysaccharide structure is based on $(1 \rightarrow 4)$-linked $\alpha$-DGalacturonic acid, interrupted by L-rhamnose residues with side chains of neutral sugars, mainly L-rhamnose, L-arabinose and Dgalactose (Akhtar et al., 2002). Galacturonic acid residues can be partially esterified by methanol on carboxyl group and by acetyl on the secondary hydroxyls (Willats et al., 2006). Pectin forms gels under certain conditions and gelling mechanism is dependent on the degree of methoxylation (DM). Pectin is divided into high methoxyl pectin with DM> 50 per cent pectins and low methoxyl (LM) pectins with $\mathrm{DM}<50$ per cent (Strom et al., 2007). Pectin with DM> 50 per cent form gels in the presence of high sugar concentration usually sucrose and fructose and low $\mathrm{pH}$, whereas pectin with $\mathrm{DM}<50$ per cent forms gels in the presence of divalent ions $(\mathrm{Fu}$ and $\mathrm{Rao}$, 2001).

\section{Important sources of pomace}

Kertez (1951) recommended Apples, citrus fruits, sugar beet and sunflower heads for pectin production. Commercially, pectin are primarily extracted from lime peel, guava extract, apple pomace (Chakraborty and Ray, 2011), orange (Braddock, 2004), cocoa husk (Mollea et al., 2008), sunflower heads (Matora et al., 1995), beet and potato pulp (Turquois et al., 1999).

\section{Particle size of raw material}

Canteri-Schemin et al., (2005) recorded 14 per cent higher pectin yield when the particle size was larger than $106 \mu \mathrm{m}$ and smaller than $250 \mu \mathrm{m}$ of apple pomace flour $(9.73 \%)$ as compared to apple pomace without grinding (6.13\%). Higher yield was due to more protopectin in small particles of the substrate than in large ones. According to Attri and Maini (1996) pectin yield from galgal (Citrus pseudolimon) increased with decreasing the particle size of the peel. Later on El-Nawawi and Shehata (1987) found of $0.075 \mathrm{~mm}$ optimum particle diameter for extraction of pectin from Egyptian orange peel.

\section{Extraction methods}

According to Joye and Luzio, (2000) the method of pectin extraction basically involves the aqueous extraction of pectin 
from the raw material, isolation, purification, and drying The yield of pectin usually depends upon the extraction conditions such as temperature, extraction time, $\mathrm{pH}$, type of extraction solvents (Yeoh et al., 2008) and drying method (Monsoor, 2005).

The most commonly used methods for the extraction of pectin are direct boiling, microwave heating (Garna et al., 2007; ElNawawi and Shehata, 1987; Liu et al., 2006), ultrasonic (Panchev et al., 1988), autoclave (Oosterveld et al., 2000) and extrusion assisted extraction. The yield of pectin depends upon extraction conditions such as temperature, extraction time, $\mathrm{pH}$ and the types of extraction material (Fishman et al., 1999; Liu et al., 2006). Khan et al., (2015) optimized temperature of $70^{\circ} \mathrm{C}$ and time 30 minutes the most suitable papameters for pectin extraction from citrus peel. whereas earlier, Chakraborty and Ray (2011) optimized extraction time of 20 to 60 minutes and temperature of 80 to $100^{\circ} \mathrm{C}$ and $\mathrm{pH} 1.4$ to 2.6 for extraction of pectin from various sources.

Azad et al., (2014) reported higher yield of pectin with distilled water having low ash content as compared to other solvents. Mollea et al., (2008); Pinheiro et al., (2008) and Fishman et al., (2006) reported that pectin can be well extracted in an acidic aqueous medium with extraction solvents such as water with mineral acids like nitric, hydrochloric or sulphuric, phosphoric and citric acids. Canteri-Schemin et al., (2005) recorded lowest pectin yields with phosphoric and malic acids while citric acid had the highest average yield of pectin (13.75\%). Zhang and Taihua (2011) reported that high methoxyl pectin can be extracted by using water or mineral acids whereas hydrochloric acid, nitric, sulphuric and phosphoric acids can generally be used for low methoxyl pectins. Rascón-Chu et al., (2009) assessed low quality 'Golden Delicious' apple fruits for acid-extraction of pectin with 6 per cent citric acid recovered pectin yield of 16 per cent. Whereas Pagan et al., (1999) observed that pectin can be extracted from banana peels, pomegranate peels, pomace of potato and peaches using aqueous acidic solution in a magnetic thermostatic stirrer. Yapo and Koffi (2006) found that the rind of yellow passion fruit can be utilized for pectin extraction by using ammonium oxalate in addition to the dilute acid solutions. Attri and Maini (1996) tried various mineral acids and organic acid extractants for pectin extraction from galgal (Citrus pseudolemon) peel and found that maximum pectin yield of 15.26 per cent on dry weight basis was obtained with $0.1 \mathrm{~N} \mathrm{HCl}$ and recommended mineral acids at lower $\mathrm{pH}$ as better extractant for maximum recovery of pectin than at higher $\mathrm{pH}$. Chan and Choo (2013) extracted pectin from cocoa husks using water, citric acid at $\mathrm{pH} 2.5$ or 4.0 , or hydrochloric acid at $\mathrm{pH} 2.5$ or 4.0 and reported that highest yield of pectin $(7.62 \%)$ was obtained by using citric acid at $\mathrm{pH} 2.5$ [1:25 (w/v)] at $95^{\circ} \mathrm{C}$ for $3.0 \mathrm{~h}$. However highest uronic acid content $(65.20 \%)$ in the pectin was obtained by using water $[1: 25$ $(\mathrm{w} / \mathrm{v})]$ at $95^{\circ} \mathrm{C}$ for $3.0 \mathrm{~h}$. Marcon et al., (2005) extracted pectin from apple pomace with 5 per cent $(\mathrm{w} / \mathrm{v})$ citric acid as extracting agent with varied time intervals (30, 50 and $80 \mathrm{~min})$ and temperature (50, 75 and $100{ }^{\circ} \mathrm{C}$ ), the maximum pectin yield $(16.8 \%)$ was obtained by using higher temperatures $\left(100{ }^{\circ} \mathrm{C} ; 80\right.$ min) and more time. Canteri-Schemin et al., (2005) extracted pectin from apple pomace aiming at establishing the optimum conditions for acid extraction using citric acid. Kalapathy and Proctor (2001) extracted pectin from soy hull using hydrochloric acid and the highest yield obtained was 28 per cent. Levigne et al., (2002) used sugar beet as substrate for pectin extraction. They studied the effect of nitric and hydrochloric acid on pectin yield and found that different kinds of pectin can be 
obtained with good yields at $\mathrm{pH} 1$. Sohair et al., (1987) extracted pectin from Egyptian orange peels using hydrochloric acid as the extracting agent, the maximum yield obtained was in the range of 21 to 30 per cent. A comparative study of pectin yield from orange peels using different acids was carried out by Shakila Bano et al., (2012) and they found that during the drying process there was a considerable difference in the pectin yield using different acids. Sayah et al., (2014) recommended the process of EO extraction then pectin isolation using citric acid hydrolysis techniques for Moroccan orange peels. Garna et al., (2007) reported that pectin extraction by using chelating agents influence the pectin functionality as residual amount of chelating agents remained in the final pectin sample. May (1990) observed that extraction of pectin by alkali cause a decrease in the degree of esterification and also reduced the length of pectin chains by $\beta$-elimination. The addition of ammonia to pectin at low temperature result in the conversion of some ester groups into amide groups.

Microwave heating extraction takes less than $15 \mathrm{~min}$ to extract a satisfactory amount of pectin (Fishman et al., 2000) and more effective in terms of pectin yield and gives better quality products (Kratchanova et al., 2004). Fishman et al., (2006) and Yeoh et al., (2008) reported that microwave assisted extraction from sugar beet pulp and orange peels under different operating conditions could extract pectin in minutes rather than hours as required by conventional heating. Koh et al., (2014) investigated the effect of power level of microwave assisted extraction $(450 \mathrm{~W}, 600 \mathrm{~W}$ and $800 \mathrm{~W})$ on yield and quality of extracted pectin from jackfruit rinds and compared with water-based extraction method at $90^{\circ} \mathrm{C}$ for extraction duration of 10 min and $1 \mathrm{hr}$, respectively. High yield of pectin was obtained from microwave assisted extraction (16.72-17.63\%) as compared to conventional extraction (14.59\%). Fishman et al., (2006), extracted pectin from lime flavedo, albedo and pulp by employing microwave-assisted extraction under pressure with heating time from 1 to $10 \mathrm{~min}$. The heating time of $3 \mathrm{~min}$ was optimized, with average molar mass ranged from about 310,000 to $515,000 \mathrm{Da}$, and average intrinsic viscosities ranged from about 9.5 to $13 \mathrm{dL} / \mathrm{g}$. Fishman et al., (2003) reported lower pectin yield from flash extraction as compared to commercial method of citrus pectin extraction but he observed that pectin extracted was comparable with microwave heating under pressure from orange albedo by steam injection under pressure.

Although the use of strong acids provides high extraction yield and time saving advantages, but it can cause serious environmental problems such as disposal of acidic waste water and also play a negative role in commuted preference. Thus several thermal or mechanical treatments have been applied to extract pectin including ultrasound (Panchev et al., 1988) autoclaving (Oosterveld et al., 2000; Hwang 2003) and subcritical water extraction (Tanaka et al., 2008). Panchev et al., (1988) and Bagherian et al., (2011) found ultrasound assisted extraction less expensive process that uses acoustic energy and solvents to extract specific compounds from various plant matrices in relatively shorter times than with conventional extraction techniques with a higher yield. Ghafoor et al., (2009) reported that the increase in extraction is mainly due to the passage of ultrasound wave to the solvent which results in acoustic cavitations. Bai et al., (2015) optimized conditions for Jujube pectin extraction with extraction parameters i.e. liquid-solid ratio (5-15), $\mathrm{pH}$ (1.5-2.5), ultrasonic time (10-20 $\mathrm{min})$ and microwave irradiation time (40-60 sec) and found best conditions for Jujube pectin extraction 10.03 $\mathrm{mL} / \mathrm{g}$ of LSR, 1.97 of $\mathrm{pH}$ of sulphuric and 
$17.66 \mathrm{~min}$ of ultrasonic time and $52.73 \mathrm{sec}$ of microwave irradiation time with the pectin yield of $1.95 \pm 0.0$ per cent. Enzymatic extraction has been shown to achieve higher recovery of pectin than other extraction methods (Panouille et al., 2006; Ptitchkina et al., 2008). Moreover, enzymatic extraction is regarded as an environmentally safe technique as enzymes degrade the pectin by selective depolymerisation. However, Panouille et al., (2006) found enzymatic extraction more expensive than other extraction methods, such as acid extraction. Yuliarti et al., (2011) evaluated the effect of celluclast $1.5 \mathrm{~L}$ on the physicochemical characterization of gold kiwifruit pectin and with different enzyme concentration $(0.1 \mathrm{ml} / \mathrm{kg}, 1.05 \mathrm{ml} / \mathrm{kg}$ and 2.0 $\mathrm{ml} / \mathrm{kg}$ ). The enzyme concentration (1.05 $\mathrm{ml} / \mathrm{kg}$ ) of celluclase $1.5 \mathrm{~L}$ resulted in the highest pectin yield and also exhibited highest viscosity.

The use of either a low level or a high level of enzyme showed lower pectin yields as the high enzyme concentration used could have resulted in greater pectin hydrolysis whereas the low enzyme concentration could have resulted in a low yield because insufficient enzyme was used for pectin extraction. Yuliarti et al., (2015) carried out the studies on extraction of pectin from gold kiwifruit from two different stages of maturity i.e. early harvested fruit and main harvested fruit isolated by three methods (acid, water and enzymatic). Pectin extracted from main harvested fruit was higher in galacturonic acid content and weight-average molecular weights compared with EHF pectins. Enzymatic treatment gave the highest yield but lowest in molecular weight. The study demonstrated that water extracted pectin exhibited the highest viscosities, suggesting that pectin obtained from water extraction method was least detrimental to the pectin molecule in the native state. Natural catalysis with endo-polyglacturonase (Conteres-
Esquivel et al., 2006), hemicellulase (Shkodina et al., 1998) with protease (Zykwinska et al., 2008) and microbial enzymes (Pichkina et al., 2008) have been used so far for extraction of pectin from different sources. Panouille et al., (2006) reported that enzymes can extract pectins with a higher yield for a smaller mass than acid extracted pectins. They further reported that the use of cellulase in the isolation of pectin from chicory roots and cauliflower. These researchers indicated that cellulase was effective in hydrolyzing the cellulose from cell wall. Pumpkin pectin has been reported to have lower gel strength $(10 \mathrm{KPa})$ when extracted by enzymes prepared from Aspergillus awamori (Pichkina et al., 2008).

The technology of plant extraction using direct induction heating assisted by magnetic field has been investigated only in the case of producing parietal fractions and fractions of secondary metabolites from wheat straw, madder roots and caraway seeds (Lagunez Rivera and Vilarem, 2007). Zoumbia et al., (2014) used electromagnetic induction for extraction of pectin from citrange albedo. They compared the protopectin of the extracted pectins with those obtained by using conventional heating. They found the time required for the extracting process was significantly reduced from $90 \mathrm{~min}$ for conventional method to $30 \mathrm{~min}$ for electromagnetic induction method as well as observed significant influence on the structural properties of pectin.

\section{Concentration of pectin extract}

The concentration of extract is done in order to reduce the volume of pectin extract so as to economize the use of precipitating agents. Kulkarni and Vijayanand (2010) recommended vacuum concentration of pectin extract for reducing the amount of alcohol required for the precipitation of the pectin 
extract. Muminov (1997) has mentioned, that the clarified extract of pectin should be concentrated in vacuum evaporator at 60$70^{\circ} \mathrm{C}$ for reducing the amount of ethanol required for the precipitation of pectin without any significant effect on the quality of pectin.

\section{Precipitation of pectin extract}

Ihl et al., (1992) studied the recovery of pectin from apple pomace ( $c v$. Pippin) by using different precipitating agents and reported higher pectin yield of 7.2 per cent with ethanol, while lower pectin yield of 1.11 per cent with 2 per cent $\mathrm{AlCl}_{3}, 2.38$ per cent with 3 per cent $\mathrm{AlCl}_{3}$ and 2.8 per cent with 4 per cent $\mathrm{AlCl}_{3}$. On the basis of high yield and acceptable properties of pectin overall precipitation with ethanol was recommended.

Attri and Maini (1996) standardized process for maximum recovery of pectin from Galgal (Citrus pseudolimon Tan.) peels and found ethanol precipitation better than aluminiumchloride precipitation on the basis of quality parameters of pectin. Muminov and Salonov (1992) has compared various precipitants i.e. polyvalent metal salts i.e. aluminium chloride, calcium chloride and copper sulphate and organic precipitants i.e. ethanol, isopropanol, acetone for pectin precipitation from cotton valves and recommended ethanol as an effective precipitating agent. Zhang and Liu (2000) found alcohol precipitation better for pectin extraction from pomelo (Citrus grandis)

Similarly Chen and $\mathrm{Li}$ (1994) reported for apple pomace pectin. Bhardwaj et al., (2014) compared ethanol ratio $1: 1,1: 2$ and $1: 3$ and found maximum pectin yield with 1:1 ethanol ratio. Arthey and Ashurst (1996) reported that pectin precipitation is governed by the addition of suitable amount of alcohol into pectin solution, which can increase the yield.

\section{Quality evaluation of pectin}

\section{Ash content}

On the basis of ash content Ranganna (1997) has differentiated the pectin as high ash content pectin (10.69 per cent ash content) and low ash content pectin ( 0.76 per cent ash content). Ramli and Asmawati (2011) extracted pectin from cocoa husk with ammonium oxalate and found highest percentage of ash content of pectin 12.93 per cent with at the extraction time of $120 \mathrm{~min}$. Virk and Sogi (2004) recorded ash content of 1.44 percent from apple pomace peel powder pectin extracted with citric acid, lower ash content in commercial pectin was 1.16 per cent. Johar et al., (1960) found that the ash content of pectin extracted from golden delicious apple pomace was 1.84 percent while Pruthi et al., (1961) observed ash content of 0.45 per cent and 0.50 per cent for mandarin pomace pectin and mandarin peel pectin respectively. Dang (1968) reported ash content of 4.79 per cent in papaya pectin, 0.70 per cent in Assam lemon pectin and 1.72 per cent in galgal pectin. Baississe et al., (2010) observed that ash content of apple and apple pomace pectin varied between 10 and 16 per cent respectively. They observed that ash content increases with increasing the precipitation, $\mathrm{pH}$ value and the concentration of aluminium sulphate. However with the use of organic solvents such as alcohol, lower ash content was recorded and it can be by increasing the lessivassion of the impurities during pectin precipitation. Mohd et al., (2012) found that dragon fruit pectin contained lower ash content with the acid than water extracted pectin. Low ash content is good for gel formation. The maximum limit of ash content for good quality gel criteria is 10 per cent. Zouambia et al., (2014) observed similar ash content in the pectin of citrange fruit following electromagnetic induction heating and conventional heating of 
extraction. Yuliarti et al., (2015) found highest ash content from gold kiwifruit purified pectin samples extracted from the early harvested fruit by the enzymatic method. They found that the enzymatic method could potentially hydrolyze the cell wall material resulting in the release of more non pectin components. However lowest ash content were obtained in water extracted main harvested fruit pectin indicating the purest form of pectin.

\section{Equivalent weight}

Equivalent weight of pectin is a measure of the total content of free galacturonic acid (not esterified) in the molecular chains of pectin (Ranganna 1997). The equivalent weight of pectin was $368 \pm 32$ to $1632 \pm 13$ in lemon pomace (Azad et al., 2014), 833.33 to 1666.30 in apple pomace (Kumar and Chauhan 2010); and 1088.9 in grapefruit peel and 818.8. in guava pomace ( Hafeez et al., 2014). Ramli and Asmawati (2011) reported that ammonium oxalate produced pectin with higher equivalent weight (580.81) compared with acetic acid (565.49) from cocoa husks and reported that the increase and decrease of equivalent weight might be dependent upon the amount of free acid. Mohd et al., (2012) worked upon characterization of pectin from dragon fruit using various extraction conditions and found maximum equivalent weight with acid extraction as compared to other methods of extraction. Kumar and Chauhan (2010) reported that equivalent weight of apple pomace pectin ranged from 833.33 to 1666.30 . Virk and Sogi (2004) reported that equivalent weight of pectin extracted from apple peel was 652.5 and commercial pectin was found to be 1030.9 . Sharma et al., (1985) recorded that equivalent weight of pectins extracted from golden delicious apple pomace and golden delicious partially ripe apples were 1384.0 and 1027.7 respectively. Shaha et al., (2013) reported 735.4 equivalent weight of pectin from kaffir lime peel dried in the microwave using hydrochloric acid extraction at $90^{\circ} \mathrm{C}$.

\section{Methoxyl content}

Methoxyl content is defined as the number of moles of methyl alcohol in $100 \mathrm{~mol}$ galacturonic acid. Methoxyl content is an important quality factor in controlling the setting time of pectins and the ability of the pectin to form gels (Constenla and Lozano, 2003). Based on the number of ester groups, the type of pectin can be categorized as low methoxyl pectin where the ester groups were less than 50 per cent and high methoxyl pectin when ester groups are more than 50 per cent. Methoxyl content present in pectin extracted from the peel of mango (7.33\%), banana $(7.03 \%)$, pomelo peel $(8.57 \%)$ lime (9.92\%) (Madhav and Pushpalatha, 2002), passion fruit $(8.81 \%$ to $9.61 \%)$ but higher than dragon fruit pectin $(2.98 \%$ to $4.34 \%)$ (Ismail et al., 2012). Azad et al., (2014) isolated and characterized the pectin extracted from lemon pomace during ripening and observed higher methoxyl content of 10.25 followed by mature and over ripe fruits. The methoxyl content decreased with increase of maturity. Due to ripening the sugar content of fruits increased and methoxyl content decreased (Sirisakulwat et al., 2008). Spreading quality and sugar binding capacity of pectin increased with increase in methoxyl content (Madhav and Pushpalatha, 2002). Hafeez et al., (2014) compared the pectin extracted from wastes of guava and grapefruits and found significantly higher 10.55 per cent in grapefruit peel than that recorded for guava pomace 8.37 per cent. Virk and Sogi, 2004 extracted pectin from apple pomace peel powder with citric acid extractant and recorded 3.7 per cent methoxyl content. Jain et al., (1984) and Sharma et al., (1985) have reported that the methoxyl content of pectin extracted from golden delicious apple pomace and golden delicious 
partially ripe apple as 8.73 per cent and 7.4 per cent respectively. The methoxyl content of pectin extracted from unblanched, washed and dried apple peel and pomace was 8.0 per cent (Chaliha et al., 1963) and of blanched one was 8.74 per cent. Srirangarajan and Shrikhande (1977) have reported 8.25 per cent methoxyl content of pectin extracted from mango peel.

\section{Anhydrogalacturonic acid (AGA) content}

Anhydrouronic acid indicates the purity of the extracted pectin and its value should not be less than 65 per cent ( Food Chemical codex, 1981). Kumar and Chauhan (2010) found 59.52 to 70.00 per cent of AGA in apple pomace pectin and commercial pectin respectively. Lo Scalzo et al., (2005) obtained high AGA content at $\mathrm{pH} 1.5$, this suggest that pectin AGA content increases with $\mathrm{pH}$ decrease and it is related to enzymatic activity decrease particularly polyglacturonase when optimum pH is 3.5 (Eskin 1990). Ferantoni et al., (2006) found AGA between 53 and 75 per cent for apple pomace. Polysaccharides such as pectin show qualitative and quantitative variations due to fruit variety, stage of maturity, geographical origin, storage condition (Veberic and Stampar, 2005) and extraction parameters (Ferantoni et al., 2006) while Ismail et al., (2012) reported 61.72 per cent and 45.25 to 52.45 per cent. Low value of AGA means that the extracted pectin might have a high amount of protein. Virk and Sogi (2004) recorded anhydrouronic acid content of pectin extracted from apple pomace peel powder was 62.8 per cent. Jain et al., (1984) and Sharma et al., (1985) have reported that the anhydrouronic acid content of pectin extracted from golden delicious apple pomace and golden delicious partially ripe apple 74.1 per cent and 73.9 per cent respectively. Jain et al., (1984) reported that pectin obtained from mango peel was reported to contain 61.1 per cent anhydrouronic acid. Lim et al., (2012) recorded that combined physical and enzymatic extraction produced pectin with 54.5 per cent of galaturonic acid as compared to 72.3 per cent with chemically-extracted pectin. Chan and Choo (2013) reported that anhydrogalacturonic acid contents of the pectin extracted from cocoa husks ranged from 31.19-65.20 per cent. Rascón-Chu et al., (2009) assessed that pectin extracted from low quality 'Golden Delicious' apple fruit presented anhydrogalacturonic acid content of 65 per cent.

\section{Degree of esterification (DE)}

It is defined as the percentage of the amount of D-galacturonic acid in which the carboxyl group passed through the process of esterification with ethyl alcohol and is important means to classify pectins. The degree of esterification varies with the fraction of raw material and precipitating agent. Massiot and Renard (1997) and Ferantoni et al., (2006) recorded 2.20 to 4.40 methanol content in apple pectin. However Renard et al., (1990) obtained highly methoxylated pectin from apples in general co-products resulting from fruit process contain pectinase, mainly pectin with low DE. Ptichkina et al., (2008) stated that pectin with $\mathrm{DE}>60 \%$ is suitable for use in the food industry. Degree of esterification is related to the rate of gel formation in food industry as it influences the quality of the gel (Pagan et al., 1999). High degree of esterification means high gelation temperature, while preparing gels by the usual procedure of mixing hot ingredients and then solidifying by cooling. Daas et al., (2001) reported that when the gel batch is cooled below the gelling temperature, gelation occurs after a delay, which is short with pectin of high degree of esterification and longer with pectin of lower degree of esterification. Rascón-Chu et al., (2009) found that pectin extracted from low quality 'Golden Delicious' apple fruit by acid 
extraction with 6 per cent citric acid presented an esterification degree of 57 per cent. Virk and Sogi (2004) found that degree of esterification of pectin extracted from apple pomace peel powder was 33.44 per cent. The degree of esterification of pectin extracted from golden delicious pomace and golden delicious partially ripe apple was 72.40 per cent and 56.9 per cent respectively (Jain et al., 1984 ; Sharma et al., 1985) whereas that of mango peel pectin was 76 per cent (Srirangarajan and Shrikhande, 1977). Ramli and Asmawati (2011) found that extraction time of 60 min produced pectin with higher degree of esterification (50.33\%) than 120 min $(49.41 \%)$ from cocoa husks, as longer extraction time might cause degradation process of methyl ester groups in pectin into carboxyl acid. Canteri-Schemin et al., (2005) found that pectin extracted from apple pomace showed a degree of esterification of approximately 68.84 per cent. Lim et al., (2012) found that the pectin extracted from Yuza (Citrus junos) pomace by combined physical and enzymatic extraction exhibited a higher degree of esterification (46\%) than chemically-extracted pectin (41\%), which was confirmed by FT-IR analysis. Hafeez et al., (2014) found significantly higher (89.23\%) degree of esterification in grapefruit peel than that of guava pomace pectin $(83.75 \%)$. Jams and preserves are of course the main use of industrially extracted pectins. High dissolved sugars and acid conditions ensure that chainchain interactions dominate once chainsolvent interactions occur (Sharma et al., 2006). Most chain-chain interactions in these systems are not based on electrostatic interaction and so the other hydrophobic and hydrogen bonding effects exert most influence. Azad and his co-workers (2014) found $\mathrm{DE}$ of lemon pomace pectin in the range of $33.59 \pm 0.17$ and $79.51 \pm 0.36$ per cent. The premature and mature samples produced high degree of esterification 79.00 \pm 0.36 and $70.39 \pm 4.20$ per cent respectively. Sotanaphun et al., (2012) and Ismail et al., (2012) reported 76.30 per cent DE in Citrus maxima and 31 to 52 per cent DE in dragon fruit. The lower DE might be attributed to the conversion of pectin into the protopectin which increase the sugars and makes the fruit softer (Bartley and Knee 1981; Redgwell et al., 1997) during the maturation due to chemical reasons occurs at too low $\mathrm{pH}$ and too high temperatures. According to Sundar Raj et al., (2012) DE actually depends upon species, tissues and stages of maturity.

\section{Structure analysis}

The infrared spectroscopy is a fast and convenient method for investigation of functional group of polysaccharides. Fourier transform infrared spectroscopic methods are useful tools in the structural characterization of natural and modified pectins as well as other plant cell wall. Polysaccharides as the contents of feruloyl groups, degree of methylation and amidation are estimated by using these spectroscopic methods (Synytsya 2003; Sinitsya et al., 2000). The study of hydrocolloids usually focuses on chemical composition, linkage between the monosaccharide units, and the size and shape of the molecule. A complete analysis of hydrocolloids or polysaccharides is unsuitable for their rapid identification in food or raw materials because the whole procedure is rather costly and time consuming. Recently, Fourier transform infrared spectroscopy has become a well accepted method for the determination of food constituents since it achieves high analysis speed and requires little or no sample preparation. Fourier transform infrared spectroscopy often coupled with chemometrics used to study different quality attributes in many food samples including fruits, vegetables or beverages e.g. epicuticular wax of apple (Veraverbeke et al., 2005), polymethoxylated flavone of orange oil residues (Manthey, 2006), vitamin C in 
powdered mixture and liquid (Yang and Irudayaraj, 2002), must and wine analysis (Fernandez and Agosin, 2007) moreover, it has become an alternative method for sugar analysis (Bellon-Maurel et al., 1995) in food such as mango juices (Duarte et al., 2002), soft drinks and fruit juices (Ramasami et al., 2004). Fourier transform infrared spectra are generally analyzed to confirm the identity of extracted pectins and to estimate their degree of esterification (DE). Kalapathy and Proctor (2001) and Wellner et al., (1998) reported that Fourier transform infrared spectra shows the functional groups and structural information of different extracted pectins and the pure pectin in the region between $1,000^{-1}$ and 2,000 $\mathrm{cm}^{-1}$. The interpretation of Fourier transform infrared spectra between 3600 and $2500 \mathrm{~cm}^{-1}$ shows broad, strong area of absorption which generally refers to $\mathrm{O} \pm \mathrm{H}$ stretching absorption due to inter and intramolecular hydrogen bonds. The $\mathrm{O}-\mathrm{H}$ stretching vibrations occur within a broad range of frequencies and indicate several features of a compound, including "free" hydroxyl groups stretching bands which occurs in samples in vapour phase and bonded $\mathrm{O}-\mathrm{H}$ bands of carboxylic acid (Silverstein et al., 1991). In the case of pectin samples, absorption in the $\mathrm{O}-\mathrm{H}$ region is due to inter and intramolecular hydrogen bonding of the galacturonic acid polymer. Finer bands appearing at the longer end of the $\mathrm{O}-\mathrm{H}$ region indicate overtones and combination of tones. Bands around $2950 \mathrm{~cm}^{-}$ ${ }^{1}$ (3000-2800 $\mathrm{cm}^{-1}$ ) refer to $\mathrm{C}-\mathrm{H}$ absorption. These include $\mathrm{CH}, \mathrm{CH}_{2}$, and $\mathrm{CH}_{3}$ stretching and bending vibrations. Typically, two moderately intense bands are observed in the $\mathrm{C}-\mathrm{H}$ region of aliphatic compounds. In pectin samples, the $\mathrm{C}-\mathrm{H}$ stretching and bending vibrations are seen, usually, as a band superimposed upon the broader $\mathrm{O}-\mathrm{H}$ band that ranges from 2500 to $3600 \mathrm{~cm}^{-1}$. In the case of esterified pectins, an $\mathrm{O}-\mathrm{CH}_{3}$ stretching band is expected between 2950 and $2750 \mathrm{~cm}^{-1}$ due to methyl esters of galacturonic acid. However, due to a large $\mathrm{O}-\mathrm{H}$ stretching response occurring in a broad region $\left(3600-2500 \mathrm{~cm}^{-}\right.$ ${ }^{1}$ ), the $\mathrm{O}-\mathrm{CH}_{3}$ activity is masked and is not a reliable indicator of methoxylation. Stronger bands occurring between $1760-1745 \mathrm{~cm}^{-1}$ and between 1640 and $1620 \mathrm{~cm}^{-1}$ indicate the ester carbonyl (C-O) groups and carboxylate ion stretching band (COO-), respectively. The bands representing ester carbonyl (1760- 1745 $\mathrm{cm}^{-1}$ ) and free carboxylate groups (1640-1620 $\mathrm{cm}^{-1}$ ) are important in the identification and quantification of pectin samples. Carboxylate groups show two bands, an asymmetrical stretching band near 1650-1550 $\mathrm{cm}^{-1}$, and a weaker symmetric stretching band near 1400 $\mathrm{cm}^{-1}$. In pectin, the weaker symmetric COOstretching is followed by moderately intense absorption patterns between 1300 and 800 $\mathrm{cm}^{-1}$ collectively referred to as the "finger print" region for carbohydrates as it allows to identify the major chemical groups (ether R$\mathrm{O}-\mathrm{R}$ and cyclic $\mathrm{C}-\mathrm{C}$ bond) in polysaccharides (Cerna et al., 2003). These bands are usually difficult to interpret. The carbonyl bands at $1630-1650$ and $1740-1760 \mathrm{~cm}^{-1}$ indicate the presence of free and esterified carboxyl groups, respectively (Gnanasambandan and Proctor, 2000). They further reported that pectin esterification degree was calculated by taking the peak areas values of the free carboxyl groups $\left(1650 \mathrm{~cm}^{-1}\right)$ and esterified groups $\left(1750 \mathrm{~cm}^{-1}\right)$ using the following equation

$$
\mathrm{DE}=\frac{\text { Area of esterified carboxyl groups }}{\text { (Area of esterified carboxyl groups }+} \times 100
$$

The FTIR spectra showed functional groups and structural information of pectin in the region between 1000 and $2000 \mathrm{~cm}^{-1}$ (Kalapathy and Proctor, 2000; Wellner et al., 1998). Cerna et al., (2003) found that the FTIR spectroscopy in the region of 1200- 800 $\mathrm{cm}^{-1}$ wavenumber region can be used as a very reliable and quick tool for food 
authentication of carbohydrate based additives.

\section{Pectin gelation}

Compression tests are suitable for determining several mechanical and rheological characteristics of different foods with respect to consumer perception. According to Szczesniak (2002) hardness and cohesiveness were defined as the force required for attaining a given deformation and the extent to which a material can be deformed before it ruptures, respectively. The gel structure is supported by soft colloidal system containing gelling agents, sugars, water and other components (Warnecke, 1991) where water acts as a plasticizer to aid gel formation (BeMiller and Whistler, 2009). The sugar co-solutes are not part of the polymer network, but they contribute to the formation and rheological behavior of confectionery gels (Morris, 1985) while the $\mathrm{pH}$ may affect gelation depending on the isoelectric point of the gelatin used among other factors (Edwards, 2000). Mitchell (1980) used experimental methods for investigating the viscoelastic behavior of gels and emphasized that the rupture tests are not the best for evaluating gels. However, with small deformation or compression tests better results can be obtained as compared with rupture tests. The gel strength and elasticity can be measured by TA-XT plus Texture Analyzer using probe number $\mathrm{P} / 0.5 \mathrm{R}$ (diameter $126.26 \mathrm{~mm}$, material delrin) with test speed $2 \mathrm{~mm} / \mathrm{s}$ and distance $25 \mathrm{~mm}$. The force should be given to the center of the gel sample. The gel strength is calculated by dividing force given with area of the probe (Marine Colloids, 1978). Rascón-Chu et al., (2009) assessed the texture profile analysis of the pectin gels and recorded increase in pectin gel hardness from 10.2 to $20.4 \mathrm{~g}$ on increasing the pectin concentration from 2 per cent to 3 per cent $(\mathrm{w} / \mathrm{v})$ which is related to the polysaccharide chain aggregation phenomena and promoted as the increase in polysaccharide concentration. The rheological stability of pectin gels at 2 per cent and 3 per cent (w/v) was determined after 48 hours at $4^{\circ} \mathrm{C}$ and it was found that after this period of storage, pectin gel hardness decreased from 10.2 to 8.2 and from 20.4 to 15.3 for the gels at 2 and 3 per cent (w/v). This rheological evolution could be due to an increase in pectin hydration as a result of a moderate acid hydrolysis of the pectin during storage. As a fact, HM pectin gels belong to the category of physically cross-linked gels whose threedimensional structure is stabilized mainly by multiple hydrophobic interactions and hydrogen bonds in the junction zones of the polymeric network (Schmelter et al., 2002).

\section{Applications}

\section{Apple pomace as a source of pectin}

According to Liu et al., (2003) Pectin can be commonly utilized as a gel forming agent in food and pharmaceutical applications. Pectin is a heteropolysaccharide made up of hydrocolloids and has been known to have applications in food industry a as gelling agent, emulsifier and stabilizer (Winning et al., 2007). Canteri-Schemin et al., (2005) has also reported the use of Pectin in processing of foods such as marmalade, jam, sauces, juices, jellies, ketchups, syrups, concentrate and yoghurts etc besides medical preparation to stabilize the suspensions. According to Aina et al., (2012) pectin has commercial uses as agglutinates in blood therapy and also thickening agent in canning of meats. Apple pomace and pectin are used for the development of soft drink, jam, Jelly, apple pomace sauce, apple pomace papad, toffee, slab, butter, bread, biscuits and cookies etc. by Johar et al., (1960); Joshi et al., (1995); Joshi et al., (1996); Barwal (1996); Kaushal et al., (2002) ; Madieta et al., (2006) and Ivy 
and Singh (2006)). Alwood (1903); Johar et al., (1960); Yasuhito (2006) and Xiaoqiong et al., (2009) have described that pomace may be used for preparation of fermented beverages viz vinegar, beer, cider, flow over alcohol and biohydrogen (bio- $\mathrm{H}_{2}$ ). There is large variety of commercial pectins available in market, differing mainly in their degrees of esterification, to meet the requirements of different jams or similar fruit containing, sugar rich, highly viscous systems (Voragen et al., 1995).

Pectin is widely used in the dairy industry, due to its stabilizing and thickening properties to prevent aggregation and precipitation of caseins, pectin is used in low acid ( $\mathrm{pH} 3.5$ 4.2) heat processed milk products (Voragen et al., 1995). Pectin can be used as a thickener in yogurts; as a water binder in stirred yogurts and as emulsifier and to provide fat-like mouthfeel in low fat yogurts. Pectin is also used in the production of fruit bases for yogurts to ensure uniform distribution of the fruit and for reducing colour migration from the fruit to the yogurt (May 1990; Voragen et al., 1995).

Pectin is used in bakery industry to retain moisture and to improve volume, flexibility and softness in breads.

In frozen dough, pectin is used to delay the retrogradation of starch, while stabilizing the volume of the dough during freezing (Brejnholt, 2010). Pectin is used in many food products such as mayonnaise, salad dressing, tomato ketchup, protein foams and beverages due to its stabilizing and thickening properties (Pilnik and Voragen 1992). Pectin is commonly used in low fat foods as a fat replacer (Min et al., 2010). Foods can be also coated with pectin and polyvalent cations prior to frying, to reduce the absorption of oil (Gerrish and Carosino 2001).

\section{Apple pomace as animal feed}

According to Rumsey (1978) apple pomace is equivalent to corn silage in total digestible nutrients content and rich in pectin, pentosans and ether extract. Further reported that inclusion of 17 per cent (dry matter basis) of apple pomace in diet of fistulated steers led to slight reduction of rumen $\mathrm{pH}$ and increased acetate to propionate ratio. Narang and Lal (1985) while evaluating some agro- industrial wastes as feed of 'Jersy' calves on the basis of body weight gains, live body measurements like height, length, breadth etc. and metabolic trials, concluded that apple pomace can safely be mixed in the feed of animals.

Conventional and unconventional by-products from the food processing industry have been frequently included in livestock diets (Denek and Can, 2006). Abdollahzadeh et al., (2010) studied the effect of replacing alfalfa hay with Ensiled Mixed Tomato and Apple Pomace (EMTAP) on performance of holstein dairy cows and reported that the nutritional value of tomato and apple pomace improved when used Ensiled Mixed Tomato and Apple Pomace together with ratio of 50:50.

Ghoreishi et al., (2007) reported that dry matter (DM) intake increased significantly when apple pomace was fed to dairy cows. Toyokawa et al., (1984) stated that the milk yield was increased when apple pomace was mixed well with wheat bran, chopped alfalfa and milled rice bran (10\% DM basis), ensiled and then fed to dairy cows.Apple pomace is traditionally utilized as cattle feed, but only a small fraction of apple pomace is used due to the rapid spoilage of the wet pomace (Bates and Roberts 2001). Apple pomace is considered as good source of nutrients due to the presence of high amounts of carbohydrate, pectin, crude fiber and minerals. Joshi and Sandhu (1994); Joshi and Sandhu (1996) have advocated innovative approach for the 
recovery of the ethanol and the production of animal feed concomitantly from apple pomace. Bae et al., (1994) compared a total mixed ration containing 39 per cent apple pomace with conventional feeds (control).

They observed that cows fed apple pomace mixed ration showed increased protein content but decreased lactose content in milk, when compared with cows fed the control diet while milk fat and solid not fat (SNF) were similar for both diets. Body weight of cows fed with apple pomace mixed ration was better as compared to cows under control feeding.

The feed cost per $\mathrm{kg}$ milk production was higher with apple pomace mixed ration but the gross income (calculated as total milk cost minus total feed cost) was higher with apple pomace mixed ration than the control. Abdollazadeh et al., (2010) studied the effect of feeding mixed tomato and apple pomace on performance of Holstein dairy cows.

Higher digestibility and palatability along with lower dry matter content of mixed tomato and apple pomace feed increased when they were mixed and ensiled. Ghoreishi et al., (2007) found that dry matter intake increased significantly when apple pomace was fed to dairy cows. According to Church (1988) and De valle et al., (2006) apple pomace has considerable amount of pectin which rumen bacteria can use to produce acetate by fermentation and leading to proper condition for milk fat synthesis.

\section{References}

Abdollazadeh F, Pirmohamammadi R, Fatehi F and Bernousi I. 2010. Effect of feeding mixed tomato and apple pomace on performance of Holstein dairy cows. Slovak Journal of Animal Science. 1:31-35

Agrahari PR and Khurdiya DS. 2003. Studies on preparation and storage of RTS beverage from pulp of culled apple pomace. Indian Food Packer. 57(2):56-61

Aina VO, Barau MM, Mamman OA, Zakari A, Haruna H, Hauwa UMS and Abba YB. 2012. Extraction and characterization of pectin from peels of lemon (Citrus limon), grape fruit (Citrus paradise) and sweet orange (Citrus sinensis). British Journal of Pharmacology and Toxicology. 3(6):259262

Akhtar M, Dickinson E, Mazoyer $\mathrm{J}$ and Langendorff V. 2002. Emulsion stabilizing properties of depolymerized pectin. Food Hydrocolloids. 16: 249- 256

Alwood WB. 1903. A study of cider making in France, Germany and England with comments and comparisons of American work. Bulletin 71. US Department of Agriculture, Bureau of Chemistry, Washington DC.114pp. 37 ill

Arthey D and Ashurst PR. 1996. Fruit Processing.1st Edn., Blackie Academic and Professional, London,pp:169-171

Attri BL and Maini SB. 1996. Pectin from galgal (Citrus pseudolimon Tan.) peel.

Azad AK, Ali MA, Akter MS, Rahman MJ and Ahmed M. 2014. Isolation and characterization of pectin extracted from lemon pomace during ripening. Journal of Food and Nutrition Science. 2:30-35

Bae DH, Sin CN and Ko KH. 1994. Effect of total mixed ration including apple pomace for lactating cows. Korean Journal of Dairy Science. 16: 295-302

Bagherian H, Ashtiani FZ, Fouladitajar A and Mohtashamy M. 2011. Comparisons between conventional, microwave- and ultrasound-assisted methods for extraction of pectin from grapefruit. Chemical Engineering and Processing. 50:1237-1243

Bai F, Wang J and Guo J. 2015. Optimization for Ultrasound-microwave Assisted Extraction of Pectin from Jujube Waste using ResSponse Surface Methodology. Advance Journal of Food Science and Technology. 7(3): 144-153.

Bartley JM and Knee M. 1981. Composition and metabolism of cell wall polysaccharides in ripening fruits, in: Recent Advances in the Biochemistry of Fruits and Vegetables, eds., J. Friend and M.J.C. Rhodes, New 
York: Academic Press, pp. 133-148

Barwal VS. 1996. Low alcoholic beverages from culled apples. Journal of Food Science and Technology. 28 (4): 257-258

Bates AW and Roberts JS. 2001. The utilization of apple pomace as a press aid in fruit juicing. In: IFT annual meeting. New Orleans, Louisiana: session 88E, Fruit and Vegetable Products: Processing. $8281 \mathrm{htm}$

Bellon-Maurel V, Vallat C and Goffinet D. 1995. Quantitative analysis of individual sugars during starch hydrolysis by FT-IR/ATR spectrometry. 1. Multivariate calibration study- repeatability and reproducibility. Applied Spectroscopy. 49: 556-562

Bemiller JN and Whistler RL. 2009. Alkaline degradation of polysaccharides. Advances in Carbohydrate Chemistry. 13: 289- 1958

Bhushan S, Kalia K, Sharma M, Singh B and Ahuja PS. 2008. Processing of apple pomace for bioactive molecules. Critical Reviews in Biotechnology. 28:285-296

Braconnot H. 1825. Nouvelles observations sur l'acide pectique. Annales de Chim ie et de Physique. 30: 96-102

Braddock RJ. 2004. Importance of byproducts to citrus juice processing. Fruit Processing.14(5): 310-13

Canteri-Schemin MH, Fertonani HCR, Waszczynskyj N and Wosiacki G. 2005. Extraction of pectin from apple pomace. Brazilian Archives of Biology and Technology. 48:259-266

Cernà M, Barros AS, Nunes A, Rocha SM, Delgadillo I, Copìkovà J and Coimbra MA. 2003. Use of FT-IR Spectroscopy as a Tool for the Analysis of Polysaccharide Food Additives. Carbohydrate Polymers. 19: 793-801

Chakraborty A and Ray S. 2011. Development of a Process for the Extraction of Pectin from Citrus Fruit Wastes viz. Lime peel, Spent guava extract, Apple pomace etc. International Journal of Food Safety. 13:391-397.

Chaliha BP, Barua AD, Mahanta D and Siddapa GS.1963.Assam lemon as a source of pectin. Part I. Effect of method of extraction, drying and storage of peel and pomace on the recovery and quality of pectin. Indian Food Packer. 17 (3):1-7
Chan SY and Choo WS. 2013. Effect of extraction conditions on the yield and chemical properties of pectin from cocoa husks. Food Chemistry. 141:3752-3758

Chen WH and Li XY. 1994. Extraction of pectin from apple peel by salting method . Food Science-China.4:22-25

Church.1988. The ruminant animal. Digestive physiology and nutrition. $2^{\text {nd }}$ edition, Prentice Hall: Englewood Cliffs, New Jersey [ISBN 0 6359-6782-4] pp IX-564

Constenla D and Lozano JE. 2003. Kinetic model of pektin demethylation. Latin American Applied Research. 33: 91-96

Contreras-Esquivel JC, Voget CE, Vita CE, Perez EJD and Renard CMG. 2006. Enzymatic extraction of lemon pectin by endopolygalacturonase from Aspergillus niger. Food Science and Biotechnology. 15:163167.

Daas PJ, Boxma B, Hopman AM, Voragen AG and Schols HA. 2001. Nonesterified galacturonic acid sequence homology of pectins. Biopolymers. 58: 1- 8

Dang RL. 1968. Better utilization of galgal. Indian Food Packer. 22 (6):16-24

De valle, Camara M and Torija ME. 2006. Chemical characterisation of tomato pomace.Journal of the Science of Food and Agriculture. 86:1232-1236

Denek N and Can A. 2006. Feeding of wet tomato pomace ensiled with wheat straw and wheat grain for Awassi sheep. Small Ruminant Research. 65:260-265

Duarte IF, Barros A, Delgadillo I, Almeida C and Gil AM. 2002. Application of FTIR spectroscopy for the quantification of sugars in mango juice as a function of ripening. Journal of Agriculture and Food Chemistry. 50: 3104-3111

Edwards WP. 2000. The science of sugar confectionary. Cambridge: The royal society of Chemistry Publishing.

El -Nawawi, SA and Shehata FR.1987. Extraction of pectin from Egyptian Orange Peel. Bioresource Technology. 55: 89-91

Eskin MNA. 1990. Biochemistry of foods. Second Edition, Academic press, New York Fernandez K and Agosin E. 2007. Quantitative analysis of red wine tannins using Fourier- Transform Mid-Infrared 
spectrometry. Journal of Agriculture and Food Chemistry. 55: 7294-7300

Factors Affecting the Extraction. Biological Wastes. 20: $281-290$

Factors Affecting the Extraction. Biological Wastes. 20: 281-290

Fertonani HCR, Scabio A, Schemin MHC, Cameiro RBB, Nogueira A and Wosiacki G. 2006. Influence of acid concentration on extraction and quality of apple pomace pectin. Semina: Ciencias Agrarias, Londrina. 27: 599-612

Fishman ML, Chau HK, Hoagland P and Ayyad K. 1999. Characterisation of pectin. Flash extracted from orange albedo by microwave heating, under pressure. Carbohydrate Research. 323:126-128

Fishman ML, Chau HK, Hoagland PD and Hotchkiss AT. 2006. Microwave-assisted extraction of lime pectin. Food Hydrocolloid. 20:1170-1177

Fishman ML, Doner LW, Chau HK and Hoagland PD. 2000. Characterization of hemicellulose B from corn fiber gum by highperformance size exclusion chromatography with on-line molar mass and viscometric detection. International Journal of Polymer Analysis and Characterization. 5: 359-379

Fishman ML, Walker PN, Chau HK and Hotchkiss AT. 2003. Flash extraction of pectin from orange albedo by steam injection. Biomacromolecules. 4:880-889

Fishman ML. Chau HK, Hoagland P and Ayyad K. 2006. Characterisation of pectin, flash extracted from orange albedo by microwave heating under pressure. Carbohydrate Research. 323:126-138

Food Chemicals Codex. 1981. 3rd ed. Washington, DC: National Academy Press. p.735.

Fox G. 1984. Zur Wirtschaftlichkeit der Trocknung von Apfeltrester. Confructa Studien. 28: 174-182.

Fu JT and Rao MA. 2001. Rheology and structure development during gelation of lowmethoxyl pectin gels: the effect of sucrose. Food Hydrocolloids. 15:93-100.

Garna H, Mabon N, Robert C, Cornet C, Nott K, Legros H, Wathelet B and Paquot M. 2007. Effect of extraction conditions on the yield and purity of apple pomace pectin precipitated but not washed by alcohol. Journal of Food Science. 72: C001-C009

Ghafoor K, Choi YH, Jeon JY and Jo IH. 2009. Optimization of ultrasound-assisted extraction of phenolic compounds, antioxidants, and anthocyanins from grape (Vitis vinifera) seeds. Journal of Agricultural Food Chemisry. 57(11):49884994

Ghoreishi SF, Pirmohamammadi R and Teimouri YA. 2007. Effect of ensiled apple pomace on milk yield, milk composition and DM intake of Holstein dairy cows. Journal of Animal and Veterinary Advances. 6:10741078

Gnanasambandan R and Proctor A. 2000. Determination of pectin degree of esterification by diffuse reflectance fourier transform infrared spectroscopy. Food Chemistry. 68: 327-332

Hafeez J, Raheem I, Aslam HKW, Shakeel A, Sakandar HA. 2014. Comparative Study of Pectin extracted from wastes from guava and grapefruit and its application in strawberry jam. Global Advanced Research Journal of Food Science and Technology. 3(6):161-169

Hwang JY, Lee CW, Wu MC and Chang HM. 2003. Transacylation and de-esterification reactions of pectin as catalyzed by pectinesterases from tomato and citrus. Journal of. Agriculture Food Chemistry. 51: 6287-6292

Ihl M, Astete G and Bifani V. 1992. Precipitation of pectins from apple pomace from the Araucania region of Chile with ethanol or aluminium chloride. Revistia Espanola de Ciencia Technologie Alimentos. 32: 185197

Ismail NSM, Ramli N, Hani NM and Meon Z. 2012. Extraction and characterization of pectin from dragon fruit (Hylocereus polyrhizus) using various extraction conditions. Sains Malaysiana. 41(1):41-45

Ivy $\mathrm{R}$ and Singh A. 2006. Response surface analysis for selection of levels of ingradients in apple pomace and bulk soyabean incorporated luscust. M.Tech. Thesis Gobind Ballabh Pant University of Agriculture and Technolgy. Pantnagar. 
India

Jain RK, Ghankrokta SS and Agrawal JD. 1984. Isolation and characterization of pectin from apple pomace. Indian Food Packer. 38(6):65-70

Johar DS, Krishnamurthy GV and Bhatia BS. 1960. Utilization of apple pomace. Food Science. 9:82-84

Joshi VK and Attri D. 2006. Solid state fermentation of apple pomace for the production of value added products. Natural product radiance. 5(4):289-296

Joshi VK and Sandhu DK. 1994. Solid State Fermentation of Apple Pomace for Production of Ethanol and Animal Feed. In : Solid state fermentation, Ashok Pandey (Ed), Eastern Wiley Publ Co., New Delhi, p 93-98

Joshi VK, Kaushal NK and Thakur NS. 1996. Apple pomace sauce development, quality of fresh and stored products. Journal of Food Science and Technology. 33: 414-419

Joshi VK, Sandhu DK and Jaiswal S. 1995. Effect of addition of SO in solid state fermentation of apple pomace. Current Science. 69 (3):263-264

Joshi VK, Sandhu DK, Attri BL and Walia RK. 1991. Cider preparation from apple juice concentrate and its consumer acceptability. Journal of Horticulture. 48:321-327

Joye DD and Luzio GA. 2000. Process for selective extraction of pectins from plant material by differential $\mathrm{pH}$. Carbohydrate Polymers. 43(4): 337-342

Kalapathy U and Proctor A. 2001. Effect of acid extraction and alcohol precipitation conditions on the yield and purity of soy hull pectin. Food Chemistry. 73: 393-396

Kaushal NK, Joshi VK and Sharma RC. 2002. Effect of stages of apple pomace collection and treatment on physio-chemical and sensory qualities of pomace leather. Journal of Food Science and Technology. 39 (4): 388-393.

Kertesz ZJ. 1951. The Pectin Substances. Inter Science, New York

Khan M, Bibi N and Zeb A. 2015. Optimization of process conditions for pectin extraction from citrus peel. Science Technology and Development. 34(1): 9-15

Knox JP. 2002. Cell and developmental biology of pectins. In: Seymour G.B., Knox J.P. (eds.), Pectins and their Manipulation, Blackwell Publishing, Oxford, p. 131-149

Koh PC, Leong CM and Noranizan MA. 2014. Microwave-assisted extraction of pectin from jackfruit rinds using different power levels. International Food Research Journal. 21(5): 2091-2097

Kratchanova M, Pavlova E and Panchev I. 2004. The effect of microwave heating of fresh orange peels on the fruit tissue and quality of extracted pectin. Carbohydrate Polymers. 56:181-185

Kulkarni SG and Vijayanand P. 2010. Effect of extraction conditions on the quality characteristics of pectin from passion fruit peel (Passiflora edulis f. flavicarpa L.). LWT- Food Science and Technology. 43:1026-1031

Kumar A and Chauhan GS. 2010. Extraction and characterization of pectin from apple pomace and its evaluation as lipase (steapsin) inhibitor. Carbohydrate Polymer. 82: 454- 459

Lagunez -Rivera L and Vilarem G. 2007. Hydrodistillation of caraway by direct induction heating-assisted by magnetic field process. Flavour Fragrance Journal. $22: 178-183$

Leroux J, Langendorff V, Schick G, Vaishnav V and Mazoyer J. 2003. Emulsion stabilizing properties of pectin. Food Hydrocolloids. 17:455-462

Levigne S, Ralet MC and Thibault JF. 2002. Characterisation of pectins extracted from fresh sugar beet under different conditions using an experimental design. Carbohydrate Polymers. 49:145-153

Lim J, Yoo J, Ko S and Lee S. 2012. Extraction and characterization of pectin from Yuza (Citrus junos) pomace: A comparison of conventional-chemical and combined physical enzymatic Extractions. Food Hydrocolloids. 29:160-165.

Liu LS, Fishman ML, Kost J and Hicks KB. 2003. Pectin-based systems for colon-specific drug delivery via oral route. Biomaterials. 24:3333-3343

Liu Y, Shi J and Langrish TAG. 2006. Waterbased extraction of pectin from flavedo and albedo of orange peels. Chemical 
Engineering Journal. 120:203-209

Lo Scalzo R, Forni E, Lupi D, Giudetti G and Testoni A. 2005. Changes of pectic composition of "Annurca" apple fruit after storage. Food Chemistry. 93:521-530

Madhav A and Pushpalatha PB. 2002. Characterization of pectin extracted from different fruit wastes. Journal of Tropical Agriculture. 40:53-55

Madieta EG, Royer R and Symoneaux FJ. 2006. Preliminary study of the production of apple pomace and quince jelly. $L W T$ Food Science and Technology. 39 (9): 1022-1025

Manimehalai, N. 2007. Fruit and waste utilization. Beverage Food World. 34 (11): 53-56 Manthey JA. 2006. Fourier transform infrared spectroscopic analysis ofthepolymethoxylatedflavone content of orange oil residues. Journal of Agriculture and Food Chemistry. 54:3215-3218

Marcon MV, Vriesmann LC, Wosiacki G, Beleski-Carneiro E and Petkowicz CL. 2005.

Marine Colloids FMC. 1978. Raw Material Test Laboratory Standard Practve. New Jersey: Marine Colloids Div. Corp. Springfield. USA. p. 79-92

Massiot P and Renard CGMC. 1997. Composition, physico-chemical properties and enzymatic degradation of fibres prepared from different tissues of apple. Lebensmittel Wissenschaft und Technologies. 30: 800-806

Matora VA, Korshunova VE, Shkodina OG, Zhemerichkin DA, Ptitchikina NM and Morris ER. 1995. The application of bacterial enzymes extraction of pectin from pumpkin and sugar beet. Food Hydrocolloids. 9: 43-46

May CD. 1990. Industrial pectins: Sources, production and applications. Carbohydrate Polymers. 12:79-99

Mitchell JR. 1980. The rheology of gels - review paper. Journal of Texture Studies. 11: 315337

Mohd NS, Ramli IN, Hani NM and Meon Z. 2012. Extraction and Characterization of Pectin from Dragon Fruit (Hylocereus polyrhizus) using Various Extraction Conditions. Sains Malaysiana. 41(1): 41-
45

Mollea C, Chiampo F and Conti R. 2008. Extraction and Characterization of pectin from cocoa husks: A preliminary study. Food Chemistry. 107: 1353-1356

Monsoor MA. 2005. Effect of drying methods on the functional properties of soy hull pectin.Carbohydrate Polymers. 61: 362-367

Muminov NS and Salomov KT.1992. Investigation and Selection of the Optimum Precipitant for Cotton Pectin [in Russian], Moscow , p. 2; Dep No. 2467, AgroNIITIpishcheprom., Jan. 181992

Muminov NS. 1997. Features of the precipitation of pectin substances From the valves ofGossypium hirsutum. Chemistry of Natural Compounds. 33(2):150-152

Narang MP and Lal R. 1985. Evaluation of some agro industrial wastes in the feed of Jersey calves. Agricultural Wastes. 13(1): 15-21

NAS, 1971. Atlas of Nutritional Data on United States and Canadian Feeds.

Oosterveld A, Beldman G, Schols HA and Voragen AGJ. 2000. Characterization of arabinose and ferulic acid rich pectic polysaccharides and hemicelluloses from sugar beet pulp. Carbohydrate Research. 328: 185-197

Pagan J, Ibarz A, Llorca M and Coll L. 1999. Quality of industrial pectin extracted from peach pomace at different $\mathrm{pH}$ and temperatures. Journal of Science Food and Agriculture. 79: 1038-1042

Pagan J, Ibarz A, Llorca M, Pagan A and Barbosa-Canovas GV. 2001. Extraction and characterization of pectin from stored peach pomace. Food Research International. 34: 605-612

Panchev I, Kirchev N and Kratchanov C. 1988. Improving pectin technology. International Journal of Food Science and Technology. 23:337-341

Panouille M, Thibault JF and Bonnin E. 2006. Cellulase and protease preparations can extract pectins from various plants byproducts. Journal of Agricultural Food Chemistry. 54: 8926-8935

Pectins from apple pomace. Polímeros. 15:127129

Pinheiro ER, Silva IMDA, Gonzaga LV, Amante ER, Teo'filo RF, Ferreira MMC and 
Amboni RDMC. 2008. Optimization of extraction of high-ester pectin from passion fruit peel (Passiflora edulis flavicarpa) with citric acid by using response surface methodology. Bioresource Technology. 99:5561-5566

Pruthi JS, Parekh CM and Lal G. 1961. An integrated process for the recovery of essential oil and pectin from Mandarin orange waste. Food Science. 10 (11): 372 378

Ptichkina NM, Markina OA and Rumyantseva GN. 2008. Pectin extraction from pumpkin with the aid of microbial enzymes. Food Hydrocolloid. 22:192-195

Ramasami P, Jhaumeer-Laulloo S, Rondeau P, Cadet F, Seepujak $\mathrm{H}$ and Seeruttun A. 2004. Quantification of sugars in soft drinks and fruit juices by density, refractometry, infrared spectroscopy and statistical methods. South African Journal of Chemistry. 57:24-27

Ramli N and Asmawati. 2011. Effect of ammonium oxalate and acetic acid at several extraction time and $\mathrm{pH}$ on some physicochemical properties of pectin from cocoa husks (Theobroma cacao). African Journal of Food Science. 5(15): 790-798

Ranganna S. 1997. Manual of analysis of fruit and vegetable products. McGraw Hill, New Delhi. p 31-65

Rascón-Chu A, Martínez-López AL, CarvajalMillán E, León-Renova NEP, MárquezEscalante JA, and Romo-CA. 2009. Pectin from low quality 'golden delicious' apples: composition and gelling capability. Food Chemistry. 116:101-103

Renard CGMC, Voragen AGJ, Thibault JF and Pilnik W. 1990. Studies on apple protopectin: Extraction of insoluble pectin by chemical means. Carbohydrate Polymers. 12: 9-25

Rumsey TS. 1978. Ruminant fermentation products and plasma ammonia of fistulated steers fed apple pomace -urea diets. Journal of Animal Science. 47:967-976

Sayah MY, Chabir R, Nadia El Mi, Kandri YRE, Chahdi FO, Touzani $\mathrm{H}$ and Errachidi $\mathrm{F}$. 2014. Comparative Study on Pectin Yield According To the State of the Orange Peels and Acids Used. International Journal of
Innovative Research in Science, Engineering and Technology. 3: 1565815665

Schmelter T, Wientjes R, Vreeker R and Klaffke W. 2002. Enzymatic modifications of pectins and the impact on their rheological properties. Carbohydrate Polymers. 47: 99108

Shah GH and Masoodi FA. 1994. Studies on the utilization of wastes from apple processing plants. Indian Food Packer. 48 (5): 47-52

Shaha RK, Punichelvana YNAP and Afandi A. 2013. Optimized Extraction Condition and Characterization of Pectin from Kaffir Lime (Citrus hystrix). Research Journal of Agriculture and Forestry Sciences. 1(2):111

Shakila-Bano M, Bharathi Kannamma G, Gayitri P, Nadezhda H and Nandhini J. 2012. Comparitive studies of pectin yield from fruits using different acids. Elixis Food Science. 42: 6349-6351

Sharma TR, Lal BB, Kumar S and Goswami AK. 1985. Pectin from different varieties of Himachal Pradesh apples. Indian Food Packer. 39 (4): 53-57

Sharma VK. 1994. Sev Ke Upiyogita-Sev Utpadan aur Sanrakashan. Him Publ, Shimla, p 1- 32

Shin HH, Kim CT, Cho YJ and Hwang JK. 2005. Analysis of extruded pectin extraction from apple pomace by response surface methodology. Food Science and Biotechnology. 14:28- 31

Shkodina OG, Zeltser OA, Selivanov NY and Ignatov VV. 1998. Enzymic extraction of pectin preparations from pumpkin. Food Hydrocolloid 12:313-316

Silverstein RM, Bassler GC and Morril TC. 1991. Infrared spectroscopy. In Spectrometric identification of organic compounds 5 th ed. New York: JohnWiley and Sons, Inc. pp. 91- 164

Sinitsya A, Copikova J, Prutyanov V, Skoblya S and Machovic V. 2000. Amidation of highly methoxylated citrus pectin with primary amines. Carbohydrate Polymers. 42: 359-368

Sirisakulwat S, Nagel A, Sruamsiri P, Carle R and Neidhart S. 2008. Yield and quality of pectins extractable from the peels of Thai 
mango cultivars depending on fruit ripeness. Journal of Agricultural Food Chemistry. 56: 10727-10738

Sohair A, E1-Nawawi and Fadia RS. 1987. Extraction of Pectin from Egyptian Orange Peel.

Sotanaphun U, Chaidedgumjorn A, Kitcharoen N, Satiraphan M, Asavapichayont $\mathrm{P}$ and Srianmornsak P. 2012. Preparation of pectin from peel of Citrus maxima. Silpakorn University of Science and Technology Journal. 6: 42-48

Srirangarajan AN and Shrikhande AJ. 1977. Characterization of mango peel pectin- a research note. Journal of Food Science. 42:279-280

Strom A, Ribelles P, Lundin L, Norton I, Morris ER and Williams MAK. 2007. Influence of Pectin Fine Structure on the Mechanical Properties of Calcium-Pectin and Acid-Pectin Gels. Biomacromolecules. 8: 2668-2674

Sun J, Hu X, Zhao G, Wu J, Wang Z, Chen F and Liao X. 2007. Characteristics of thin-layer infrared drying of apple pomace with and without hot air pre-drying. Food Science and Technology International 13(2):91-97

Sundar Raj AA, Rubila S, Jayabalan R and Ranganathan TV. 2012. A review on pectin: Chemistry due to general properties of pectin and pharmaceutical uses. Scientific reports. 1(2): 1-4

Synytsya A, Copíková J, Matejka P and Machovic V. 2003. Fourier transform Raman and infrared spectroscopy of pectins. Carbohydrate Polymers. 54(1): 97-106

Szczesniak AS. 2002. Texture is a sensory property. Food Quality and Preference. 13: 215- 225

Tamaki Y, Konishi T, Fukuta $\mathrm{M}$ and Tako M. 2008. Isolation and structural characterization of pectin from endocarp of Citrus depressa. Food Chemistry. 107: 352362

Tanaka M, Wallace IS, Takano J, Roberts DM and Fujiwara T. 2008. NIP6;1 isaboric acid channel or preferential transport of boron to growing shoot tissues in Arabidopsis. PlantCell. 20:2860-2875

Toyokawa K, Saito Z, Inoue T, Mikami S, Takayasu I and Tsubomatsu K. 1984. The effects of apple pomace silage on the milk production and the reduction of the feed cost for lactating cows. Bulletin of the Faculty of Agriculture-Hirosaki University. 41: 89-112

Turquois T, Rinaudo M, Taravel FR and Heyraud A. 1999. Extraction of highly gelling pectic substances from sugar beet pulp and potato pulp: Influence of extrinsic parameters on their gelling properties. Food Hydrocolloids. 13: 255-262

Vasil'ev YI, Morozov AN, Zaiko GM and Moiseeva VG. 1976. The utilization of waste from vegetable and fruit canning plants. Konservnaya-i-Ovoshchesushil naya-Promyshlennost. 3: 32-34

Vauquelin M. 1790. Analyse de tamarin. Analytical. Chemistry. 5: 92

Veberic R and Stampar F. 2005. Selected polyphenols in fruits of different cultivars of genus Prunus. Phyton. 45: 375-383

Veraverbeke EA, Lammertyn J, Nicolaï BM and Irudayaraj J. 2005. Spectroscopic evaluation of the surface quality of apple. Journal of Agriculture and Food Chemistry. 53: 1046- 1051

Virk BS and Sogi DS. 2004. Extraction and characterization of pectin from apple pomace (Malus Pumila CV Amri) peel waste. International Journal of Food Properties. 7: 1-11

Voragen AGJ, Pilnik W, Thibault JF, Axelos MAV and Renard MGC. 1995. Pectins. In: Food polysaccharides and their applications. A. M. Stephen, ed. Marcel Dekker, Inc.: New York, USA. pp 287-340

Wellner N, Kacuraakova M, Malovõakova A, Wilson RH and Belton PS. 1998. FT-IR study of pectate and pectinate gels formed by divalent cations. Carbohydrate Research. 308: 123-131

Willats WG, Knox JP and Mikkelsen JD. 2006. Pectin: new insights into an old polymer are starting to gel. Trends in Food Science and Technology. 17:97-104

Winning H, Viereck N, Norgaard L, Larsen J, Engelsen SB. 2007. Quantification of the degree of blockiness in pectins using $1 \mathrm{H}$ NMR spectroscopy and chemometrics. Food Hydrocolloids. 21:256-266

Xiaoqiong F, Hui W, Yu W, Xiaofang $\mathrm{W}$ and 
Jianxin H. 2009. Biohydrogen production from apple pomace by anaerobic fermentation with river sludge. International Journal Hydrogen Energy.30:1-7

Yang $\mathrm{H}$ and Irudayaraj J. 2002. Rapid determination of vitamin $\mathrm{C}$ by NIR, MIR and FT- Raman techniques. Journal of Pharmacy and Pharmacology. 54: 12471255

Yapo BM and Koffi KL. 2006. Yellow passion fruit rind - A potential source of lowmethoxyl pectin. Journal of Agriculture Food Chemistry. 54: 2738-2744

Yapo BM, Robert C, Etienne I, Wathelet B and Paquot M. 2007. Effect of extraction conditions on the yield, purity and surface properties of sugar beet pulp pectin extracts. Food Chemistry. 100: 1356-1364

Yasuhito M. 2006. Flavor alcohol production from apple pomace by high-ethyl caproateproducing strain of sake yeast. Journal of Brewing Society Japan. 101 (9): 711-716

Yeoh S, Shi JTAG and Langrish TAG. 2008. Comparisons between different techniques for water-based mextraction of pectin from orange peels, Desalination. 218:229-237

Yuliarti O, Matia-Menno L, Goh MJA and Brcnnan CS. 2011. Effect of Cclluclast $1.5 \mathrm{~L}$ on the Phvsico-chemieal Characterization of Gold Kiwifruit Pectin.
International Journal of molecularScience.12: 6407-6417

Yuliarti O, Matia-Merino L, Goh KKT, Mawson J, Williams MAK and Brennan C. 2015. Characterization of gold kiwifruit pectin from fruit of different maturities and extraction methods. Food Chemistry. 166: 479-485

Zhang C and Liu ZW. 2000. Studies on the conditions for conditions for precipitation of extracted pectin in pomelo peel. Science and Technology of Food Industry. 21(5):2931

Zhang C and Taihua MU. 2011. Optimisation of pectin extraction from sweet potato (Ipomoea batatas, Convolvulaceae) residues with disodium phosphate solution by response surface method. International Journal of Food Science and Technology. 46(11): 2274-2280

Zouambia Y, Ettoumi KY, Krea M, Mostefa NM.2014. A new approach for pectin extraction: Electromagnetic induction heating. Arabian Journal of Chemistry. 30:1-8

Zykwinska A and Boiffard MH, Kontkanen $\mathrm{H}$, Buchert J, Thibault JF and Bonnin E. 2008. Extraction of green labeled pectins and pectic oligosaccharides from plant byproducts. Journal of Agriculture and Food Chemistry. 56:8926-893.

\section{How to cite this article:}

Devina Vaidya, Anil Kumar Verma, Anil Gupta, Manisha Kaushal, Shivani and Vinay Chandel. 2020. Agro-Industrial Solid Biodegradable Waste as a Source of Pectin and Feed for Livestock Farm - An Appraisal. Int.J.Curr.Microbiol.App.Sci. 9(06): 2457-2476. doi: https://doi.org/10.20546/ijcmas.2020.906.299 